\title{
EROTIC-OSMOTIC COMPLEX AS THE ESSENCE OF POSTMODERNISM: PHILOSOPHICAL ASPECT
}

\section{Natalia Opryshko ${ }^{1}$}

DOI: https://doi.org/10.30525/978-9934-588-15-0-111

Abstract. The research under consideration studies the phenomenon of erotic osmosis in contemporary culture in the attempt to show its relevance in postmodern philosophical discourse. The latter thus becomes the object of the research while its subject covers various manifestations of eroticism in postmodern culture. Using such methods of analysis as semiotic decoding, concept reading and transdisciplinary reading, the author claims the postmodern erotisism to have clearly recognizable osmotic nature. Proving this idea has become the purpose of the research. Results of it show that the process of osmosis as the interaction of liquids with different concentrations through the walls of a thin membrane is well known in natural sciences (Biology, Chemistry, Medical Science etc.). Since the 1970s, the concept of osmosis has been introduced into the cultural, and later religious and philosophical context. Therefore, it is possible to use it in Humanities (e.g. inliterary criticism, cultural studies and contemporary philological research). An attempt to do it has already been made by Kalyaga (Poland) when analyzing the intertextual nature of postmodern writings. In addition, the concept of osmosis is extremely important in the field of deconstruction, in particular, in the theory of difference, which assumes, above all, the presence in the text of certain faces, membranes, filters. Thus, erotic osmosis becomes an organic manifestation of postmodernism in general, since love, in particular, its sensual form 'É $\rho \omega \varsigma$ structures the modern 'post-love' world. In this context, we can also talk about the osmotic nature of postmodern eroticism, which, by the principle of chaosmosis, filling the space between different constituents of the postmodern text, is relevant to each of the textual planes. In one way or another, the manifestation of eroticism is reflected on all the text levels - from the plot to the process of writing and interpretation, correlating with the postmodern notion of «eroticism

\footnotetext{
${ }^{1} \mathrm{PhD}$, Assistant Professor at the Chair of Philology and Linguodidactics,
} Kharkiv National Automobile and Highway University, Ukraine 
of text», with the nonlinearity of postmodern thinking, and again with the phenomenon of rhizome as a nonlinear concept. Postmodernism is impossible without eroticism, sometimes even identical to it. Endowed with a heterogeneous structure and devoid of traditional integrity, dissolved in the space of postmodern textuality between its various components, so that, using the term natural sciences, it could be described as a connective tissue, osmotic in its functions and nature, postmodern version of the bodily love has become a part of postmodern paradigm, a characteristic feature of the postmodern world.

\section{Introduction}

Osmosis, the process of penetration and dissolution of outlying elements in a particular environment, is a natural point in the philosophy and aesthetics of postmodernism, although the concept of osmosis is extremely rare for various philological studies, and ours is just one of the possibilities of introducing the concept into the present day philological and / or philosophical discourse. To do so, we shall analize the reasons for this, the first - and the main one - of which is the fact that postmodernism is intertextual in nature, whereas osmosis is the principle and way in which intertext exists. But the term «osmosis» is not just a correlate of the intertextuality concept. On the one hand, it is a kind of diffusion of different texts, discourses, cultures, which provides dialogue as one of the leading features of postmodern literature. On the other hand, the understanding of osmosis is here correlated with the term «chaosmosis», introduced by J. Joyce to denote the contamination of chaos, cosmos and osmosis as the basic principles of the construction and functioning of a postmodern text. The chaosmotic space is the territory that exists between the known logocentric science systems of total ordering and absolute anarchy, and at the same time the territory that unites them in an indissoluble whole, and thus allows the osmotic processes of interpenetration and mutual dissolution to occur in such a complex and complicated way. Discussing the postmodern discourse, we can speak not only about its nonlinear structure, but also about the unstable, diffuse nature.

Yet, a postmodern text, though diffused and chaotic - is an extremally balanced integrity. In nature, such a balance is actually established by osmosis. The function of osmosis as a process of dissolution is stressed by Wojciech Kalyaga. He refers to this phenomenon as synonymous with the 
concept of «intertextuality» in the context of literary criticism, where osmosis is identified with nebularity - a nebula that attests to the blurred frames of postmodern text in contrast to the clearer orderliness and seclusion of other texts. Thus, it is logical to appeal to osmosis as an opportunity to distinguish between classical, modern and postmodern text, in which chaosotic processes are most fully traced, and blurring, quotation, collage and multiple meanings become the main features. Without rejecting the wording of the Polish scientist, as well as the theory of the chaos by Gilles Deleuze and Felix Guattari, this study uses the term «osmosis» to delineate the total diffusion of the erotosphere of the postmodern text.

The use of the concept inherent in natural scientific discourse in the context of philological studies is not accidental, especially if one resorts to the basic principle of postmodernism - its exceptional methodological discursiveness, which at the same time is combined with non-discursive, chaosotic perception. In a nebulous chaosomic environment, the boundaries of any concept or phenomenon change too rapidly, transform into one another, change due to the influence of internal and external factors, and generate an infinite number of interpretations, which, in the end, result in an inherent postmodern «scattering of meanings». Indeed, according to Philip Kubersky, the Sciences, the Humanities and the fiction discourses are inextricably combined in the postmodern age, and such a combination expresses a new level of self-organization of the world and the place of the subject («Me») in it. The novelty of our work is determined by the changing nature of postmodernism, where every new approach requires a different type of reading and interpriting to trace the organic connection of eroticism and osmosis to a contemporary text, and more broadly - to contemporary philosophy and poetics.

The purpose of the paper is to prove the feasibility of using the term «erotic osmosis» in the context of postmodern studies, which has not been done before. Achieving the goal of work involves discussing the following tasks: to determine the essence of osmosis as a defining feature of postmodern discourse and to prove the osmotic nature of postmodern love. Taking the specifics of the subject and tasks of the study in mind, the work was performed within the framework of the semiotic method, the methods of conceptual and transdisciplinary reading of the text, which provide for the interpretation of its models as organic integral codes. 
The scientific novelty of the dissertation and the personal contribution of the author are a systematic analysis of the philosophy of postmodernism through the prism of erotic osmosis. This studio significantly deepens the concept of postmodernism, which implies the presence of deconstruction, reveals the nature of eroticism in postmodern thinking, as well as contributes to a deeper understanding of the worldview and aesthetic foundations of contemporary philosophical and literary process.

\section{The concept of osmosis in postmodern studies}

Postmodern theorists emphasize the crisis nature of postmodern consciousness. Specific vision of the world as chaos, without causality and value orientations, a kind of decentered world, which presents the human consciousness only in the form of mechanically disordered fragments. It is generaly defined as the postmodern sensitivity, one of the key concepts in postmodernism. Fragmentary and chaotic, devoid of a logical center and exceptionally plural in meaning, postmodern culture is likened to a human being immersed in a living cell. This cell is in constant interaction with the environment: elements of heterogeneous cultures penetrate into each other, dissolve, affect each other, and these mutual effects often occur spontaneously, without a proper order or intention. These processes are, actually, most accurately reflected by the term «osmosis», borrowed from the natural sciences.

Traditionally, «osmosis» (from Greek «push, pressure») means spontaneous transition, unilateral diffusion through a semi-penitrable partition (a membrane) that separates a solute from a pure solvent or a solution of less concentration [see: 27]. Such a partition transmits small molecules of solvent, but is impermeable to larger molecules of solute. Equalization of concentrations on both sides of it is possible only in case of the solvent unilateral diffusion. Therefore, this process always moves from a pure solvent to a solute or from a dilute solute to a concentrated one. The transfer of the solvent through the membrane is conducted due to osmotic pressure. It is equal to the excess external pressure that must be applied by the solute to stop osmosis, that is, to create conditions of osmotic equilibrium, or rather osmotic balance which guarantees the existence of a healthy living cell.

For the first time the phenomenon of osmosis interested French researcher Antoine Nolle in the mid-eighteenth century, being more explored in the 
nineteenth and twentieth centuries, in particular, by Ludwig Traube, who worked on ways to create an artificial membrane, Wilhelm Pfeffer, who researched the features of osmotic phenomenon, Van der Waals, and later a number of other scientists, with active research on osmotic processes continuing to this day.

In the cultural sense, osmosis becomes a mechanism for the interaction of different cultures, as well as for individual elements within the same culture. Such a vision of the diffusion of cultures, their capacity for interpenetration is not something unusual and new in the postmodern glossary, nor is it new to involve the experience of the natural sciences for a more accurate and detailed understanding of various phenomena in postmodernism, including literary studies. After all, as the Polish researcher Severina Wysloch notes, the polyphony of contemporary literature is difficult to grasp fully without the involvement of interdisciplinary connections, without the possibility of applying them in the sphere of interpretation, since the «theory of interpretation» appeals «to the interdisciplinary interpretation of the problematics, and the researchers are free in their choice of the subjects» [24, p. 311-312]. Moreover, according to Richard Nich, the concept of the text «activates the whole etymological-vocabulary nest, in its biological-medical-weaving-printing-philosophical dimensions, i.e. as matter of fabric, structure of the canvas, weave, grid, variety of printing, graphically recorded sequences of linguistic signs, forms of verbal works, etc» [22, p. 56], and this lexicon emphasizes the natural involving in the text analysis the conceptual apparatus of both tangible and distant spheres and disciplines.

It should be noted here that the term «osmosis» is used by one of the theorists of postmodern philosophy Roland Barthes. In his work «Mythology» (1957), reflecting on the phenomenon of children's creativity, the researcher uses it to denote the mutual influence (cultural and psychological) between the world of adults and the child's world. «To believe in the poetic genius of childhood is to believe in a certain literary parthenogenesis and once again to declare literature a gift of God,» R. Barthes emphasizes. - Yet, any imprint of «culture» is considered a sign of falsification, as if nature is closely following the words, as if the child did not live in constant osmosis with the environment of adults; metaphoricity, imagination, spontaneity become the hallmarks of childhood, whereas in reality they are the products of hard work - conscious 
or subconscious - and imply a depth of thinking in which the most important role is given to the degree of individual maturity» [2, p. 49].

The metaphor of osmosis in the 1970s became broader and deeper, acquiring a striking philosophical and cultural colouring. Particularly noteworthy is the fact that the term «osmosis» is used by a church representative, which speaks of the popularity of the term in the 1970s, when interdisciplinary ties were becoming widespread in the context of the deconstructivism, post-structuralism and postmodernism development. We mean here the article «Cultural Osmosis» by Abbot Gennady (Yevgeniy Eykalovich), a religious figure of Russian immigration who lived in Europe and America, so he could be acquainted with the latest trends in cultural and philosophical thought, though considered it to have a clear and hierarchical structure. Gennady's theory reflects a purely modernist view of the author on the phenomenon of cultural osmosis in general and its embodiment within Russian culture in particular, which becomes a direct object of the abbot's study. It should be taken into account that the author of the modernist strategy gives the people the priority right to become the embodiment of culture and open to alien elements, because in modernism, a person is able to learnt the world and tranfer the knowledge into creativity, while the era of postmodernism demonstrates rational, sound criticism to the power of a human in this area. It is only natural for the abbot Gennady to begin his text with the biblical parable of the Sower. In an attempt to answer the question of how Western European ideology was able to be combined with a completely different Russian culture, Abbot Gennady addresses the metaphor of osmosis. He writes about the extremely complex relationships between cultural environments in human society, dependent on many forces and factors, incapable of any calculating by the means of the Mathematics. Therefore, it is easier to relate to the natural siences, as the relations between such cultural environments, the establishment and development of them has a lot in common with the phenomena of wildlife: «Introduction of a cultural phenomenon from one cultural environment to another can fluctuate between two extremes that may rarely be encountered in reality - between complete osmosis and complete colloid» [14, p. 213]. It is a process peculiar to culture in all its multiplicity of manifestations, that is, the phenomena of religious, philosophical, ethical, social, aesthetic sphere, etc. Moreover, the phenomena of ideological nature tend to migrate first «horizontally» (from 
one educational environment to another), and then later «vertically» (borrowing it from higher, educated strata of society by the lower). Analyzing different types of such borrowing, Abbot Gennady concludes that the rate of diffusion, socialization and transmission in the case of cultural osmosis depends on such factors as «the persistence and versatility of the need that would satisfy the phenomenon, the congregationality of the host culture, the force of priming in its implementation and appropriately organized propaganda» $[14$, p. 214]. In addition, the responsibility for how effectively and quickly a new culture enters a certain phenomenon is obviously the responsibility of the culture itself. According to Mr. Eikalovich's theory, culture is not a passive screen on which a particular phenomenon is projected. On the contrary, since it perceives new elements from the very beginning, it must «remain active in the desire to open up to a new influence, in the desire to replace the usual psychological and social reflexes with new norms of thought and behavior» [12, p. 216].

The researcher emphasizes that the dissolution of alien elements in a particular culture sometimes happens so slowly that this process goes unnoticed, however, there are areas of manifesting such cultural «emulsion». And for a more detailed examination, the author quite rightfully uses the classification of sociologist Pithyrim A. Sorokin, citing his «Modern historical and social philosophies» (New York, 1963). The point is that the elements of another culture may enter the body of the host culture in different ways, as are the types of cultures regarding the ability to perceive alien elements. Thus, any cultural phenomenon transitions freely and without visible transformations from one culture to another, provided that «the culture of origine is identical to the culture of infiltration» [12, p. 213]. However, if two cultures involved in the process are heterogeneous, the migrating cultural phenomenon changes, and this change is proportional to the degree of differentiation of these cultures. In the case of incomplete affinity, which is referred to here, «the soil is partly fertile, partly rocky, sometimes arid» $[12$, p. 215] - the Abbot Gennady theorizes in a completely pastoral manner - alien elements are absorbed into the body of a new culture with different intensity.

In the case where the affinity of cultures is partial, we can speak about the intrinsic nature of a cultural phenomenon that seeks to dissolve in another culture that makes such a transition possible. Abbot Gennady, com- 
menting on this point in Sorokin's book, thinks that cultural phenomena simpler in nature «infiltrate» faster and easier than complex, and the latter, including artificial, tend to simplify. A model of absolute rejection of elements from a foreign culture by a new culture may also occur if the distance between them is insurmountably large. Then the cultural phenomena, which the author calls «infiltrates» (also a term borrowed from the field of natural sciences), remain alien to the discourse of culture they fall into, so, we are dealing with the opposite of osmosis - the gradual and final dissolution of a new element in the culture-host.

Thus, it is no wonder, that modern literary criticism has borrowed the term «osmosis» to denote the exceptional diffusion of postmodern text, which correlates with the classical notion of intertextuality, because, in the opinion of Gilles Deleuze and Felix Guattari, «the book imitates the world in the same way as art imitates nature, through processes that are inherent to it and successfully complete what nature is unable or no longer able to do» [31, p. 132]. Considering the osmotic nature of the postmodern text as its main, defining feature, the researchers thus explain the possibility of a permanent dialogue between the inner and outer spaces of the text, and more broadly - the universal nature of the principle of dialogicity that structures the entire world of postmodern culture. Like a cell of a living organism that «communicates» with the environment through the constant movement of liquids and their dissolved substances through the thin walls of the cell membrane, the word in postmodernism «is not an independent and separate brick, which serves to erect the same independent and separate structure of the text; the word changes, develops, it is a living element of discourse, which always remains in dialogue with its cultural, ideological, social and linguistic environment» [31, p. 149]. Therefore, the boundaries of the text, relative to the cell membrane in this case, cannot remain passive constraints given a priori, but must «allow for intermittent osmosis, interpenetration and exchange between internal and external worlds of the text» [ibid], transforming monologue expression in a permanent dialogue or rather a polylogue of texts and discourses, transforming scattered fragments into a sort of orderly integrity.

However, despite the intent to overcome its chaotic nature, postmodernism is defined as a cultural formation, a historical period, or a set of theoretical and artistic movements characterized by principled eclecticism 
and fragmentation, a rejection of grand, all-encompassing worldviews and narratives. The «enlightening» desire to find the ideal, the search for a certain universal and rationally attainable truth is equated with the dangers of utopianism and totalitarianism. The world is perceived and understood as text, as «endless transcoding, the play of signs beyond which it is impossible to find meaningful things as they really are, truth in itself» [29, p. 12]. Each individual text, and modern culture in general, is considered «intertextually», as a game of conscious and unconscious borrowings, quotes, clichés, allusions and more. The concept of reality is constructed as a derivative of those conceptual schemas and textual strategies that depend on the researcher's racial, ethnic, gender, sexual identities and orientations, on his or her own positions and aspirations. Instead of unity and opposite categories, there are categories of «the different» and «the other» that proclaim the value of the «other» beyond the system. Any hierarchy of values is leveled for the coexistence of different cultural models and canons that are self-contained, self-contained, and not reducible to one another.

Thus, the image of a chaotically constructed, too complex, and sometimes artificially complicated system naturally becomes a metaphor for contemporary art culture, against which postmodernism is seen as a reflection of a world devoid of knowledge and feelings, of a world that breaks into fragments that are desperately trying to recover. through stylistic eclecticism, intertextual influences, collage and parody of reality. Declaring war on «unity», «integrity», «oneness», postmodern philosophy simply cannot afford to understand the surrounding reality, neither as chaotic nor cosmically hierarchized, since both options will be manifestations of a certain structure not appropriate for postmodernism. The way out of this situation was offered by Gilles Deleuze in his work «The Logic of Meaning» (1969), in which the real being is represented by the immanent identity of chaos and space, where the play of meaning and nonsense take place. Therefore, meaning, before being born, must come to chaos, be on the verge of nonsense. Under these conditions, the haphazard, chaotic and dialogical «mosaic puzzle of postmodernism» (Wil Mirimanov) becomes an objective reproduction of the fragmentation of our ideas, «the inability of art to grasp the depths of mysteries of the universe» [21, p. 34].

Indeed, according to Russian researcher Sergei Zenkin, contemporary literature is purely dialogical in nature. Writers seeking to preserve their 
identities against the backdrop of the interpenetration of cultures, styles and texts resort to the typical postmodern game, and such a game with the text can be both self-contained and aggressive, denying its predecessor, that is, the author or the text engaged in the dialogue with a postmodern text, and the system of literature in which it operates. According to S. Zenkin, the corresponding «aggressive parody» turns into one of the most important means of dynamic literary evolution at a time when «diffuse-fragmentary interaction of texts, which does not pursue system-polemical goals, approaches in its sense rather than the concept of « intertextuality» by Jeanette» $[13$, p. 71$]$. Intertextuality is inherently present in postmodern text in such a way that two or more texts are contained within it in the same space, and it is the interpreter who must restore this dialogue, extracting all conscious or unconscious author's intentions from the intertextual space.

According to Yulia Kristeva, such dialogism is identical to the deep structures of discourse. Therefore, in order to understand and describe its nature, it is necessary to «interpret the mental mechanism of writing as follows the dialogue of the author with himself (with The other), as a form of author's self-distancing, as a way of splitting the writer into a subject of expression-process and subject of expression-result» [19, p. 176]. Therefore, it is logical that this subject-subject dialogue, which structures any narrative process, can be traced precisely at the level of discourse, because, according to the French researcher, the story is always created as a «dialogical matrix», and this dialogue, a sign, the ambivalence of writing is found in making of the discourse, that is, in the plane of literary text, exclusively shown in certain narrative structures.

Thus, postmodernism, which is in constant dialogue with other cultural and philosophical searches and exists on the principles of total intertextuality, absorbs all existing artistic traditions, but, taking them out of historical context, creates an eclectic collage, devoid of the traditional center, clarity, temporal and cultural coordinates, which corresponds to the picture of the postmodernist world - the world of decay, destruction, the post-love world. As American postmodernist John Barthes notes, «postmodernism is an artistic practice that pulls the juices of life from the culture of the past, the literature of exhaustion» [1, p. 125]. And the metaphor of the tree sucking the juice, necessary for the existence, out of the earth, in the context of postmodern discourse is not accidental. This is the way, in which, according 
to the principle of osmosis, postmodern culture creates a field that is dominated not by rational, logically designed philosophical reflection, but by the deeply emotional, internal response of modern people to the world around them. Postmodern culture is a territory situated not just at the intersection of chaos (anarchy) and space (order), but between them, equally tangible to both of these planes and at the same time equidistant from them. This gives rise to the phenomenon of «postmodern sensibility», a specific percepting the world as chaos, lacking any criteria of value and meaning orientation. Such a worldview, thereafter, is expressed at the level of the composition of texts in an effort to reproduce the chaos of life by artificially organized chaos of a fundamentally fragmentary narrative, the components of which are intertwined on the principle of chaosmic rhizome-root. And this intertwining is a blending-contamination, when each of the components, when combined with the other, does not lose its own peculiarities, and at the same time it is osmosis, which provides for the strict selection and filtering of intertextual elements as opposed to uncontrollably scattered nebularity.

\section{Osmotic nature of postmodern eroticism}

Eroticism becomes the most organic sphere of exposing the postmodernism's osmotic nature, given that osmosis and eroticism are completely homogeneous concepts. And so the romantic text is the perfect landscape for the osmosis manifestation, because, as Roland Barthes notes in the preface to «Fragments of the Lover's Language» (1977), «one should not regard the lover as the bearer of certain symptoms, but rather try to hear everything irrelevant that is not exposed, but is present in his voice. Hence the choice of a «dramatic» method that abandons examples is based solely on the actions of the primary language (not meta-language). Thus, the description of the love discourse is replaced by its simulation, and this discourse is given its fundamental image, namely «I», in order to show the whole act of expression, not analysis. A portrait is offered if you wish; but this portrait is not a psychological one, but a structural one; it must be viewed in a certain place of language - the place of a person who's speaking (the lover) in front of the other (the beloved) person who is not speaking now» [3, p. 13].

$\mathrm{Yu}$. Kristeva reffers to this phenomenon as the transgression of the linguistic code, which becomes possible and ambivalent only by the ability to establish a «different law» for itself (Kristeva), different from the laws 
that used to determin classical, non-fragmentary discourse. Dialogue, then, is not a freedom to say anything, but «a mockery, for the most part tragic, an imperative, but not such as an imperative of the "unity» [18, p. 126]. Thus, the dialogue of postmodern Kristeva's text is seen as the transgression, requiring a definite break with the norm, thus presupposing the establishment of exceptional interconnection between the units of the text. So, different intertextual elements are combined in the text, penetrate into each other, are transformed and propagated in the plane of the postmodern discourse on the principle of osmosis, because transgression itself implies the phenomenon of crossing the boundary that cannot be ignored, and first of all, we mean here the boundaries between the possible and the impossible, which are conducive to the impossibility, osmoticity, overcoming any restrictions, including textual ones. According to Georges Bataille, transgression has always been manifested in extraordinary artistic forms. That is why it is so organically disclosed precisely within the framework of an indecent, romantic narrative, because, according to Foucault, sexuality is the object and instrument of transgression [28, p. 129].

It is worth noting that love - both emotional and sensual - became a manifestation of postmodern axiology from the very beginning. And it is not surprising, because at the turn of the XX - XXI centuries the concept of love, popular during the previous epochs, could no longer coincide with the whole human experience and the corresponding perception of life. Viktor Malakhov emphasizes that «in a world where so many values are opposed to each other, each claiming our love, the latter can no longer ignore its limitation... Love, which paradoxically combines pity and admiration, eroticism and compassion, more and more today is getting a value of a certain human constant for the various spheres of manifestation of this feeling wherever it is still able to «take root» in our postmodern and post-apocalyptic reality» [20, p. 126].

In order to examine the explication of sensual love motives in the postmodern text, firstly, we offer to trace classic models of love-eros in the traditional romance.

Understanding love as a measure of humanity in a man, as a meaning-forming metanormative factor in our life is rooted in the philosophy of the ancient Greeks, which, according to Plato, was known for four types of love: eros, filius, storghe and agape. Since then, philosophers have tried to 
make similar classifications that would reflect the deeply aporetic nature of love: for example, love-need and love-gift (Clive Staples Lewis); pathological and true love (Emmanuel Kant); brotherly love, maternal love, erotic love, self-love and love for God (Erich Fromm), etc. [see: 20]. At the same time, the erotic (physical) aspect of love is, one way or another, essential even in ideologically and philosophically distant paradigms.

Eros is considered to be a kind of love, which includes spiritual and sexual elements, where «the sexual one prevails on the basis of its genetic primacy» $[15$, p. 510$]$. There are two points of view on love-eros. «Radically Erotic Eros» [4, p. 101] is most accurately expressed in the terms of sexual attraction, thirst for possession, desire to complete integrity: «Sexual love is a generalizing type of any other love» [4, p. 101]. If Eros is sublimated, that is, «ennobled» (this is a moderate view of the nature of Eros), then «no matter how much this poet's sense is magnified, it can be defined in no other way than the word 'need.' For love is a person's idea of the need of the person to whom he or she is attracted» [6, p. 78]. No matter how passionately that love manifests itself, it is directed only at the object, a means of satisfying its (now to a certain extent, «high») desires. In this way, Eros absorbs culture. Erotic motifs had always been present in literature from antiquity (Daphnis and Chloe by Long) and the Middle Ages (the Tristan and Isolde novels) until the 19th century. In the 1840 s, the total fascination with Georges-Sandev's ideas of free love and the reviving of the flesh, connected with the left-Hegelian philosophy of action, led to the fact that love for a woman was regarded as «the first atonement for a man's sinful inaction» [7, p. 142]. Positivist perceptions of love were drawn from Augustus Comte's «positive philosophy», which asserted the authority of the senses and, at the basic level, sensuality by which «a man becomes one with himself» [9, p. 143], and from Ludwig Feuerbach, who saw in all-consuming love the only effective remedies for selfishness inherent in a man. Thus, if romanticism viewed perfect (platonic, «pure») love and Eros as two fundamentally different feelings, «that can be experienced by someone at the same time and be directed at different objects» [9, p. 142], then positivism considered incorporeal love a «chimera», something that could never exist. Sensuality started to be associated with health, strength and energy as opposed to the apathy of romantic-sentimental love. The ideal of passive suffering caused by the object of love (for example, in Johann-Wolfgang Goethe's Young Werther Suffering) 
was replaced by the perception of this feeling as a source of vital energy for inner self-improvement and intelligent restructuring of the world. In the Russian literature of that period it is possible to note the concept of «positive erotology» by Nikolai Chernyshevsky and Alexander Pushkin's philosophy of Eros, where the poet's creativity emphasizes the enormous energetic value of sensual love, its ability «to fuel» amazing transformations... in the pursuit of perfection, immortality» [8, p. 33]. From a philosophical point of view, a certain concept of eroticism was presented by Arthur Schopenhauer in his treatise «Metaphysics of Sexual Love» (1819), which sharply contrasted the brains of a man and his genitals, characterized as the focus of all willpower. «The metaphysics of sexual love» is a kind of reservation not to succumb to love, which is, above all, an «individualized sexual instinct» [25, p. 149], capable of bringing only suffering to men. Schopenhauer, who preferred the idea of «not being born» [25, p. 149], proclaimed hatred of women because they «did not want to end the suffering of humanity - to give birth» $[25$, p. 150]. Discussing the issue with A. Schopenhauer, a Russian philosopher Vladimir Solovyov emphasized that sexual love in a man is not identical to the instinct of reproduction, and «generic goals» are achieved separately from «individual love» [25, p. 150]. But recognizing childbirth as «happiness for the mother», he simultaneously considers it a kind of «atonement» given to a man as a result of participation in the «animal breeding process» [25, p. 149]. Just like A. Schopenhauer, V. Solovyov felt the enmity of nature, of its «generic element» concerning the human personality, its spiritual essence. According to Solovyov, «the genital act embodies the infinity of the natural process in which the blind force of life perpetuates itself at the expense of the born and the dead... ». In fact, according to the philosopher, only a genius can resist this ridiculous infinity, a man capable of spiritual creativity, whose moral position resists dark and blind forces of nature. According to Schopenhauer, the juxtaposition of the spiritual personality to the clan included the concepts of humanism and morality. Galina Time [25] notes that Solovyov found his sense of love in critical thinking of Schopenhauer, in whose outlook he «asserted a will identical to the flesh, and broke through the rebellion of human personality» [25, p. 153]. Solovyov's experience is a typically modernist strategy of finding his own set of meanings metatextually - by disputing with the predecessors and commenting on their point. 
Postmodernism, in its turn, refers to modernism the way pleasure refers to desire. If modernism and its predecessor realism - an era of desire and an era of knowledge - united in the desire for the depths of the world, in an attempt to expose its hidden essence, then postmodernism is a «pleasure incivilization» (Epstein), different from Freudian and Marxist dissatisfaction. Therefore, postmodernism can be regarded as «erosemiotics - almost sensual enjoyment of signs, texts, all the conventions of civilization, its alienated forms, sorting through quotations and styles, marked or not» $[30$, p. 215]. But at the same time, indissolubly linked to pleasure, desire constantly moves in the direction of discontent, where in the long run the images of temptation merge with the images of death, and therefore postmodernism as a temporary homeostasis of desire-pleasure is inseparable from the inevitable end, that is, the return to primordial chaos. According to this idea, the concept of chaos in postmodern thinking is transformed, «it is transferred from the margins to the center of philosophical and cultural reflections» $[11, \mathrm{p} .424]$. Thus, the attention of postmodern researchers focuses not on the denial of the universe of the existing, but rather on the transformation of it, on the creation of a universe that undergoes evolution from chaos to cosmos (actually chaosmosis). Moreover, the orderly cosmos implicitly involved in chaos transpires in it. Jean-François Liotard associates it with the concept of «instability», since instability, the loss of faith in the metanarrative, is a characteristic feature of post-modern times. And once again, instability is endowed with creative abilities - in a text that is devoid of original meaning, any potential semantics are possible, and the space of actualization becomes unlimited in general.

The metaphor of cosmos as orderly chaos, locked in certain, though rather dubious boundaries, is also used by Wojciech Kalyaga. He views a text, and especially a postmodern text, not only as a space for total transformation and self-ordering, but also as a correlate of the holographic nebula, which conveys the most successful one of the basic properties of the text - its dialogicality: «In its virtuality, the text is unable to exist outside the relationship, as it can not avoid entering into new relationships from the moment when the configuration of the semiotic space in the process of changing such relationships throws it: taken by the interpretive paradigm, the text is forced to respond and enter into a relationship. Even though the virtual nebulae of the text has - or has never - been noticed or discovered in a particular act of reception, they 
are distributed in the form of differentiated and variable condensations in different directions of discursive space» [24, p. 166].

Accordingly, text does not need, and cannot require, any boundaries (frameworks, restrictions, etc.) as self-asserting and outlining its identity. In fact, the a priori text is placed between the various poles of postmodern reality - order and its absence. So, in the world of the postmodern text, another function of osmosis is realized - to achieve equilibrium, balance between these opposites, just as osmosis in nature is conditioned by the desire of the organic system for thermodynamic equilibrium. It is love that acts in the postmodern text as a catalyst or even a driving force for such osmosis, that is, it is a certain solvent capable of breaking the boundaries between the individual structural elements of the text. It seems legitimate that the very concept of osmosis as a way of achieving integrity is transferred by postmodern philosophers to the plane of love and relations between lovers. For example, thinking about Jan Kefelek's novel «Osmosis» (2004), Olga Pakhanova [see: 16] gives the metaphor of osmosis to a sort of relationships in which two people are constantly in a situation of mutual attraction-repulsion, that is, they conflict with each other, but cannot live separately from each other at the same time. This vision of the interaction between the loving and the beloved makes it possible to argue that in the age of postmodernism, the love discourse not only becomes an ideal territory for postmodernist searches, but also predetermines their exclusively osmotic nature: on the various levels of artistic text, it binds them together, consolidates them, transforms them into a new integrity, but also separates them from each other in their quest for finding a lost equilibrium.

Since postmodern sensibility inherently implies a co-presence, a clash of discursive (rational) and poetic plans, the artistic (literary) text is the point of intersection of sufficiently clear models of the sexuality philosophy, presented at all levels of creating and understanding the text as a purely osmotic phenomenon. Contrary to modernist aesthetics, for postmodernism, sexuality is concentrated not only and not so much in the sphere of sensual love. Rather, it is a philosophical concept that captures in its contents all the characteristics of human corporeality, which enables the constitution of variable culturally articulated practices of sex as the creation of the erotic sphere of human life. The content of the sexuality concept is defined in postmodern philosophy under the influence of several paradigmically sig- 
nificant vectors. It is formed in the general context of the post-metaphysical style of thinking known for the "postmodern sensibility», which is oriented to the «refusal to see the unchanging noumenal basis in the phenomenal sphere» [23, p. 706]. Interpretation of sex as a completely physiologically determined and therefore constant phenomenon in the classical cultural tradition has changed in the postmodern intention to find in the historically specific configurations of sexual practices, used by a particular culture, the semiotic articulation of sexuality as such. According to Michel Foucault, «in cases of flesh and sexuality, there is no one area that unites everything; when it is true that «sexuality» is the totality of effects produced in bodies, in behavior, in social relations by the action of a certain dispositive, it must be admitted that this dispositive does not act symmetrically here and there» $[26$, p. 233]. This asymmetric, diffuse, decentralized action is a direct feature of category of the sexuality and its osmotic nature.

Thus, sexuality is interpreted by postmodern philosophy in the context of the general concept of problematization, according to which the absence of a rigidly defined legitimation of a particular cultural sphere leads to its "constitution as a subject of reflective speculations and rational analysis»" $[23$, p. 706]. According to the postmodern vision of the situation, the most important factor in problematizing a phenomenon in a cultural context is not the size and strength of the prohibitions that limit it, but rather the freedom of its spontaneous development. Thus, according to Foucault, the modern era is characterized by an unprecedented desire for sexual expression, the so-called «talking of and about sex» [26, p. 77], even if in the form of its verbal or textual explication.

The semantics of the sexuality concept is expressed in postmodernism «under the semantic-axiological influence of the concept of simulation, fundamental to postmodernism, which is based on a comprehensive semiotization of being» [23, p. 706], that is, on the call for total rejecting the rationalistic method of philosophizing the thinkers used to have before. Among other things, this includes awareness of erotic-sexual models. Thus, M. Foucault argues that sex is an instrument of oppression that is put forward by repressive civilization for its defense. In the opinion of the philosopher, the more people think about sex, the more dependent they are on sex. In this way, the authorities penetrate into the realm of intimacy, creating the necessary order for it, based on the criteria of truth, so people try to find this truth 
about sex in psychoanalysis. At the same time, the French postmodernist does not support the technological control of sexuality based on the idea of truth. In his opinion, annexation of sex in the field of rationality, offered by Western culture, put the person (our body, soul, individuality, history) under the logic of lust and desire, and the moralists made a man to be an offspring of sex - in the form of advice and recommendations of specialists, a kind of life management technique that, according to M. Foucault, is a new form of government. This explains the philosopher's rather skeptical attitude towards Sigmund Freud and Jacques Lacan, who, although they abandoned the simplistic hypotheses of sex suppression, still maintained traditional notions of power in terms of «essence», «localization», «desire». M. Foucault notes in no uncertain terms that power is not derived from any point of view or an institution of domination, it is ubiquitous and multidimensional, it is an immanent form of life, capable of manifesting itself in various social institutions, including the family. It captures the soul and body of a man, and the only way out, the only means of struggle, is to return to oneself, to take care of oneself, the way it used to be in antiquity, when Dionysian gymnastics, diet, erotica, and methods of self-control were opposed to daily life restraint. In the end, Foucault also transferred power and sexuality as an ontological quality of a man into the sphere of discourse, although in the postmodern era, the semiotization of sex has unexpectedly led to its gradual disappearance as a result of the implementation of the strategy of abrasion from the body any gender signs, the emergence of «body-prosthesis» concepts, a virtualization of pleasure.

But regardless of the perception of sexuality as a function or as a structural discourse, an entity that exists under political economy thinks and sexually defines itself in terms of equilibrium (equilibrium of functions under conditions of personal identity) and connectedness (structural connectedness of discourse under conditions of endless code playback). In this case, the body remains ambivalent, both an object and an anti-object, which crosses and abolishes all disciplines aimed at achieving its unity. On the other hand, the body is a «topos-antitopos»: the topos of the subconscious as the antitopos of the subject and the like. In the light of the postmodern philosophical paradigm, modern psychoanalysis (Serge Leclair), separating the body from the anatomical and the erogenous, initiates the process of desire in the writing mode - on behalf of the body. Therefore, the privileged 
subversive position conferred on the body by its displacement is terminated by its present emancipation. But at the same time, the «liberated» body gradually loses the symbolic potencies that had previously been endowed with the «suppressed» body, and thus the «spoken» body, introducing it into the plane of verbal discourse, becomes definite, even in some ideas, the opposite to the speaking body itself. In the postmodern aesthetics of the body as a topos, where the primary processes take place, the body opposes the secondary process - erotic consumption value, axiological rationalization. The desire-craving body is opposed to the body, semi-organized, structured, theatricalized in the secondary nudity, functionalized by operative sexuality. Such a secondary body, a body of sexual emancipation and «repressive desublimation» (Jean Baudrillard) appears solely as an erotic model, and gender is regarded only as the principle of Eros - that is, they are mutually neutralized by the declared desire for death.

The contents of the sexuality concept is defined in the context of a new understanding of determinism, in which any state of the phenomenon under study «is understood not as a product of causal influence from the outside, but as a result of an autochthonous and autonomous process of self-organization» [23, p. 707]. It is on this principle that Georges Bataille views the history of eroticism as an exclusively human model of sexuality, arguing that eroticism is inherently human sexual activity, as opposed to the same activity of animals. According to the philosopher, not every form of human sexuality is erotic in nature, but it becomes one, as soon as it gets rid of the elemental animal sexuality. So, he means associations and judgments with the intention of sexual qualification of objects, beings, places, and times in which there is nothing sexual, although they do not contain anything that contradicts sexuality [see: 5, p. 13]. Thus, the «erotosphere» is formed precisely under the influence of the internal process of transformation and reorganization.

Such a transformation is quite natural: researchers of the postmodern age, who note the crisis nature of postmodern consciousness, say about a certain extinction of feelings, about the inability of postmodern man to high romance. However, on the background of total doubt, in a world that has forever lost its light of true feelings, a new need for them has never been felt so strongly before. It is this need that leads to living the love, talking it through, according to the law of postmodern aporethology, that reduces 
high romance to the enumeration of various sexual practices. Such love, carnal, low, understandable and accessible to everybody, love, identified by the ancient Greeks with Aphrodite Pandemos, reveals the secondary nature of this concept in postmodernism. But the postmodern sensibility is paradoxical: unable to create true feeling, the post-love world still needs love, seeks to fill its lack. Thus, according to Georges Bataille, eroticism becomes the exclusive sphere of human existance, for which the spiritual aspect is no less important than the corporeal, since it reveals «the transition from the mere sexuality of the animal to the mental activity of man implied by eroticism» $[5$, p. 24].

In the context of postmodern nomadology, sexuality is seen as «potentially and topically plural» [23, p. 707]. The nomadological approach, which interprets its subject matter as fundamentally nonlinear, treats sexuality in the same way, unlike sex, which is always teleologically linear. Thus, the sexual sphere of life is characterized by a postmodern philosophical strategy, «the replacement of vertical and hierarchical connections by horizontal and rhizomatic, the rejection of the idea of linearity, metadiscursiveness, universal language, and thinking based on binary dyads» [30, p. 65]. In their work Rizomé (1976), scientists Gilles Deleuze and Felix Guattari compare the world not with the tree that characterizes the modern tradition, but with the rhizome - a system of small roots, each of which is equal in their structured world. Because, by Deleuze and Guattari's definition, «one of the basic properties of rhizome is to have a large number of exits» [30, p. 82]. This definition clearly describes the very affinity of the postmodern text as such that can be read differently by anyone who takes and opens it. This completely postmodern assertion, however, cannot be percieved without a return to Friedrich Nietzsche's reasoning that there are no facts, only interpretations - our understanding of them under the influence of certain life circumstances, and rhizomes, integrally encompassing the philosophy of postmodern organization of integrity, reveals in particular the notion of postmodern love-erotica as one of the key notions in postmodernism.

Considering the principles of the category of sexuality outlined in postmodern philosophy and aesthetics, we can distinguish hypersexuality as one of the leading features of postmodernism. Hypersexuality, by the definition of the Russian researcher Mikhail Epstein, is the hyperbolization of sexuality, which exists in both the works of Z. Freud and the novels of 
D.G. Lawrence, and at the most primitive level - in numerous pornographic editions that embody the idea of hypersexuality at the level of mass culture [see: 30, p. 33]. The ambiguity, danger, even death of spiritual Eros also originates from the aesthetic, not the ethical, dominant of erotic ascent to perfection. The absolute is transcendental to the empirical world, and the purpose of Eros is to be a bridge, a union of the immanent and the transcendental, materially corporeal and perfectly holistic. The primary attraction then goes not to the good, but to the beauty that connects the two worlds absolute life and temporary existence. In beauty, according to Yevgeniya Krasnukhina, «our basic erotic passion, our salvation and our death» is hidden [16, p. 27]. Beauty is engendered by the presence of both principles the bright, intelligent Apollonian source of measure and form and the dark passionate instinctive Bacchus impulses of the Dionysian source, which in turn appeal to different aspects of a human being: the Eros of spiritual enrichment and the Eros of personal ruin.

Thus, the postmodern vision of love-eros, which, on the one hand, is characterized by its reduction to sex, and on the other hand, apologizes, emphasizing its leading role in human development, both at the level of philosophical and artistic landscapes, provides for exceptional diversity and diffusion of sex explications. Such an apology of corporeality in the love-sensual sphere naturally leads to a specific interpretation of love by the Menipei, which underlies cynicism as a means of salvation in a world of lost, neglected values. However, regardless of the perception of sexuality as a function or as a structural discourse, it is through it that constant dialogue between the inner and outer spaces of the postmodern text becomes possible. This process, in fact, is described by Wojciech Kalyaga as «discursive osmosis», closely linked to the universal nature of the principle of dialogical texts, or intertextuality, since any text, in general, and postmodern love discourse, in particular, is not a closed territory of static structures and meanings, but has become a natural part of the dialogic discourse of world cultures.

\section{Conclusions}

Taking into account all the facts mentioned above, we can come to the conclusion that in the context of postmodern rejection of logocentrism, the exceptional dialogicality of the postmodern text is explained precisely by the osmotic nature of modern and post-modern love, which becomes similar 
to the connective tissue in the space of post-love discourse. Postmodern eros acquires the characteristics of the ultra-sensitive membrane, which allows the diffusion of different elements and their dissolution within the text, and at the same time connects various elements of the text into a single unity. Therefore, erotic osmosis is perceived as an actual infinity, so it permanently gives rise to specific love forms and practices, each of which is finite. Thus, in an environment of erotic osmosis, any version of eros embedded in a postmodern context receives the semantics of the final act, structuring the boundary of sexuality as boundless a priori. It is defined by postmodernism as «permanent formation» and therefore articulated as non-final, since it is centered not on «pleasure», in which the process devoid of purpose disappears, but on «enjoyment», essentially infinite and unclosed in its core.

\section{References:}

1. Bart Dzh. (1997). Literatura istoshcheniya [The literature of exhaustion]. Russian literary journal, vol. 10, pp. 117-135.

2. Bart R. (1994). Udovol'stvie ot teksta. Izbrannye raboty: Semiotika. Poetika [The pleasure from the text. Selected works: Semiotics. Poetics]. Moscow: Progress. (in Russian)

3. Bart R. (2003). Fragmenty rechi vlyublennogo [The fragments of a lover's speech]. Moscow: Ad Marginem. (in Russian)

4. Batay Zh. (2002). Iz «Slez Erosa» [From the 'Tears of Eros']. Tanatografiya Erosa [Thanatography of Eros]. St. Petersburg: Mifril, pp. 273-308.

5. Bataj Zh. (2004). Istorija erotyzmu [The history of eroticism]. «Ji». Independent cultural journal, vol. 33, pp. 12-34.

6. Berdyaev N. (1991). Metafizika pola i lyubvi. Russkiy Eros, ili Filosofiya lyubvi v Rossii [Metaphisics of gender and love. Russian Eros, or The philosophy of Love in Russia]. Moscow: Nauka. (in Russian)

7. Berdyaev N. (2007). Eros i lichnost': Filosofiya pola i lyubvi [Eros and Personality: The philosophy of gender and love]. St. Petersburg: «Azbukaklassika». (in Russian)

8. Gachev G. (2004). Russkiy Eros («Roman» Mysli s zhizn'yu) [Russian Eros ('Romance' of the Thought and the Life)]. Moscow: Eksmo, Algoritm. (in Russian)

9. Derrida Zh. (2012). Vokrug Vavilonskikh bashen (Des tours de Babel) [Around the towers of Babilon]. St. Petersburg: Ex-Machine. (in Russian)

10. Vinkvist Ch., Tejlor V. (2003). Encyklopedija postmodernizmu [Encyclopedia of postmodernism]. Kyiv: Osnova. (in Ukrainian)

11. Zhycinsjkyj Ju. (2004). Bogh postmodernistiv [God of postmodernists]. Lviv: Publishing of Ukrainian Catholic University. (in Ukrainian)

12. Zenkin S. (2000). Vvedenie v literaturovedenie: Teoriya literatury: Uchebnoe posobie [Introduction to Literary Studies: The theory of literature: Tutorial]. Moscow: Russian State University of Humanities. (in Russian) 
13. Igumen Gennadiy. (1975). Kul'turnyy osmos [Cultural Osmosis]. The Facets, no. 98, pp. 215-237.

14. Kaljaga. V. (2008). Tumannosti tekstu [The nebulae of the text]. Teorija literatury v Poljshhi: Antologhija tekstiv. Drugha polovyna XX - pochatok XXI st. [Literature theory in Poland: Anthology of texts. The second half of the XX - the beginning of the XXI century]. Kyiv: Publishing ‘Kyiv-Mohyla Academy', pp. 141-171.

15. Kefelek Ya. (2004). Osmos [Osmosis]. Moscow: AST, Ermak. (in Russian)

16. Krasnukhina E. (1995). Eros smerti [The Eros of death]. The figures of Thanatos. Philosophical almanac, vol. 5, pp. 23-27.

17. Kristeva Yu. (2002). Diskurs lyubvi [The discourse of love]. Tanatografiya Erosa [Thanatography of Eros]. St. Petersburg: Mifril, pp. 101-109.

18. Kristeva Yu. (2004). Izbrannye trudy: Razrushenie poetiki [Selected works: The destruction of Poetics]. Moscow: ROSSPEN. (in Russian)

19. Malakhov V. (2002). Uyazvimost' lyubvi [The weakness of love]. The Issues of philosophy, no. 11, pp. 231-237.

20. Markuze G. (2003). Eros i tsivilizatsiya. Odnomernyy chelovek: Issledovanie ideologii razvitogo industrial'nogo obshchestva [Eros and civilization. One-dimensional man: The studies on ideology of a developed industrial society]. Moscow: AST. (in Russian)

21. Nych R. (2007). Svit tekstu: poststrukturalizm i literaturoznavstvo [The world of the text: poststructuralism and literary studies]. Lviv: Litopys. (in Ukrainian)

22. Gritsanov A.A., Mozheyko M.A. (2001). Postmodernizm. Entsiklopediya [Postmodernism. Encyclopedia]. Minsk: Interpresservis, Knizhnyy Dom. (in Russian)

23. Morenecj V. Teorija literatury v Poljshhi: Antologhija tekstiv. Drugha polovyna XX - pochatok XXI st. [Literature theory in Poland: Anthology of texts. The second half of the XX - the beginning of the XXI century]. Kyiv: Publishing 'Kyiv-Mohyla Academy'. (in Ukrainian)

24. Time G. (1999). Metafizika polovoy lyubvi kak metalyubov' (ot A. Shopengauera $\mathrm{k} \mathrm{Vl}$. Solov'evu) [The metaphisics of bodily love as a metalove (From A. Shopengauer to Vl. Solovyov)]. The issues of philosophy, no. 6, pp. 145-153.

25. Fuko M. (1998). Istoriya seksual'nosti: Zabota o sebe [The history of sexuality: Care about yourself], vol. 3. Kyiv: Dukh i litera, Moscow: Refl-book. (in Russian)

26. Fuko M. (2002). O transgressii [About the transgression]. Tanatografiya Erosa [Thanatography of Eros]. St. Petersburg: Mifril, pp. 113-131.

27. Brokgauz i Efron. (2009). Entsiklopedicheskiy slovar' [Encyclopedic dictionary]. Kyiv: «Kovcheg». (in Russian)

28. Epshteyn M. (2005). Postmodern v russkoy literature: Ucheb. posobie dlya vuzov [Postmodern in Russian literature: Tutorial for higher educational establishments]. Moscow: «Vysshaya shkola». (in Russian)

29. Epshteyn M. (2006). Filosofiya tela [The Philosophy of the Body]. Telo svobody [The Body of Freedom]. St. Petersburg: Aleteyya, pp. 102-123.

30. Deleuze G., Cuattari F. (1976). Rhizome.

31. Lyotard J.-F. (1983). Answering question: What is postmodernism? Innovation. Renovation: New perspectives on the humanities. 